\title{
HUBUNGAN PELAYANAN PHLEBOTOMY DENGAN KEPUASAN PASIEN DILABORATORIUM KLINIK RUMAH SAKIT TNI AU DR. SUHARDI HARDJOLUKITO YOGYAKARTA
}

\author{
Ratih Hardisari \\ Jurusan Analis Kesehatan Poltekkes Kemenkes Yogyakarta \\ Email : ratihhardisari@gmail.com
}

\begin{abstract}
Patient satisfaction is an important quality indicator of hospital performance, especially for clinical laboratory services. At the moment, services given by medical laboratory technologist personnel in blood sampling section are not optimal. Air force Hospital Dr. Suhardi Hardjolukito Yogyakarta, a public hospital in Bantul, has clinical laboratory which serves patients from the members of Indonesian military, civil servants, general patient, patients with health insurance coverage and also patients with national health insurance program (Jamkesmas). This study was aimed to know the correlation between phlebotomy services and patient satisfaction in clinical laboratory of Air Force Hospital Dr. Suhardi Hardjolukito Yogyakarta. It was a quantitative observational study with cross-sectional study. The data were collected from August $21^{\text {st }} 2016$ until September $6^{\text {th }}$ 2016. The population of the study was taken from all outpatients of clinical laboratory in Air Force Hospital Dr. Suhardi Hardjolukito Yogyakarta, by using simple random sampling. The data were collected by observing using check list, questionnaire, and document analysis with likert scale level measurement. The result of this study showed from 94 respondents which were differentiated as five quality service dimensions of patient satisfaction: $88,3 \%$ for dimension of reliability, $86,9 \%$ for dimension of quality assurance, $86,1 \%$ for dimension of empathy, $83,8 \%$ for dimension of responsiveness, $78,6 \%$ for dimensions of tangibles. Statistical analysis showed that there was a correlation between phlebotomy service and patient satisfaction $(p<0,1)$.
\end{abstract}

Keywords : Patient, Service, Phlebotomy, Satisfaction

\begin{abstract}
ABSTRAK
Kepuasan pasien merupakan hal yang penting dalam meninjau mutu pelayanan suatu rumah sakit khususnya pelayanan laboratorium. Saat ini pelayanan yang diberikan oleh tenaga analis kesehatan dibagian pengambilan darah masih belum optimal. Rumah sakit Pusat TNI AU Dr. Suhardi Hardjolukito Yogyakarta adalah rumah sakit pemerintah yang berkembang di wilayah Bantul, memiliki Instalasi Laboratorium yang melayani pasien dari anggota TNI, PNS ,umum, pengguna asuransi kesehatan serta pasien jamkesmas. Penelitian ini bertujuan untuk mengetahui hubungan antara pelayanan phlebotomy dengan kepuasan pasien di laboratorium klinik RS Pusat TNI Angkatan Udara Dr. Suhardi Hardjolukito Yogyakarta. Jenis penelitian ini adalah penelitian observasional yang bersifat kuantitatif dengan metode cross sectional study. Pengumpulan data dilakukan pada tanggal 21 Agustus sampai dengan 6 September 2016. Populasi pada penelitian ini adalah semua pasien rawat jalan yang melakukan pemeriksaan laboratorium di RSP TNI AU Dr. Suhardi Hardjolukito, menggunakan metode simple random sampling untuk pemilihan sampel pasien.Teknik pengumpulan data adalah dengan observasi, kuisioner dan dokumentasi. Skala pengukuran menggunakan skala likert. Hasil penelitian terhadap 94 responden diperoleh hasil kepuasan rata- rata berdasarkan lima dimensi mutu kualitas pelayanan yaitu dimensi kehandalan $88,3 \%$, dimensi jaminan $86,9 \%$, dimensi empati $86,1 \%$, dimensi responsivitas $83,8 \%$, dimensi wujud $78,6 \%$. Dengan uji korelasi product moment didapatkan hasil p lebih kecil dari 0,1 , maka $\mathrm{H}_{1}$ diterima dengan demikian dapat disimpulkan bahwa ada hubungan antara pelayanan phlebotomy dengan kepuasan pasien.
\end{abstract}

Kata Kunci : Pasien, Pelayanan, Phlebotomy, Kepuasan

\section{PENDAHULUAN}

Pembangunan kesehatan sebagai bagian dari upaya pembangunan nasional yang menyeluruh, terarah, terpadu dan berkesinambungan diwujudkan untuk memenuhi unsur kesejahteraan masyarakat sesuai dengan cita- cita bangsa Indonesia. Berbagai kegiatan yang dilakukan dalam rangka mencapai pembangunan kesehatan tidak akan lepas dari dukungan sumber daya di bidang kesehatan. Begitu juga peranan sumber daya manusia bidang kesehatan, khususnya tenaga kesehatan sangat berpengaruh terhadap kualitas pelayanan kesehatan yang diselenggarakan dalam rangka mewujudkan arah tujuan pembangunan kesehatan, yaitu derajat kesehatan masyarakat yang setinggi-tingginya' .

Pelayanan Laboratorium kesehatan merupakan bagian yang tidak terpisahkan dari pelayanan kesehatan kepada masyarakat. Laboratorium 
kesehatan sebagai unit pelayanan penunjang medis, diharapkan dapat memberikan informasi yang teliti dan akurat tentang aspek laboratories terhadap specimen atau sampel yang pengujiannya dilakukan di laboratorium. Masyarakat menghendaki mutu hasil pengujian laboratorium terus diitingkatkan seiring dengan kemajuan ilmu pengetahuan dan teknologi serta pengembangan penyakit ${ }^{2}$.

Di dalam memberikan jasa pelayanan yang baik kepada pasien, terdapat lima penentu kualitas jasa yaitu : kehandalan, responsivitas, jaminan, empati dan wujud. Kelima unsur tersebut menjadi acuan untuk menentukan kepuasan pasien ${ }^{3}$

Dengan mengetahui, mengenali, memahami kebutuhan pelanggan maka dapat diketahui apa yang harus dilakukan dan dikerjakan dalam memberikan pelayanan yang tepat sesuai dengan apa yang diinginkan dan dibutuhkan pelanggan, berusaha memberikan pelayanan yang terbaik dan maksimal kepada pelanggan sehingga dapat memuaskan pelanggan dan pelanggan akan merasa diperhatikan dan dipentingkan dalam mendapatkan informasi yang dibutuhkan ${ }^{4}$.

Saat ini pelayanan yang diberikan oleh tenaga analis kesehatan dibagian sampling atau pengambilan darah masih belum optimal, hal ini dibuktikan dengan masih adanya keluhan karena ketidaknyamanan yang dirasakan oleh pasien terkait dengan pelaksanaan tindakan pengambilan darah. Informasi dari pasien tersebut dapat dijadikan ukuran kesesuaian antara keinginan dan harapan pasien terhadap kualitas yang diterima, sehingga meningkatkan kualitas pengambilan darah vena atau phlebotomy ${ }^{5}$.

Laboratorium Klinik Rumah Sakit Pusat TNI Angkatan Udara Dr. Suhardi Hardjolukito merupakan rumah sakit angkatan udara yang melayani pasien dari anggota TNI, PNS, umum, pengguna asuransi kesehatan serta pasien jamkesmas.

Berdasarkan studi pendahuluan yang dilakukan peneliti pada bulan April 2016, ditemukan beberapa keluhan yang menyangkut kualitas pelayanan yang diberikan oleh laboratorium klinik RS Pusat TNI Angkatan Udara Dr. Suhardi Hardjolukito Yogyakarta pada tahun 2014, diantaranya: mengeluhkan keterampilan petugas pada saat pengambilan darah vena (phlebotomy), kurangnya komunikasi kepada pasien dan ruang tunggu yang kurang nyaman. Tetapi pihak laboratorium belum melakukan analisis kepuasan pasien secara lengkap dan mendalam terhadap setiap keluhan pelanggan tersebut .

Tujuan penelitian ini adalah untuk Mengetahui hubungan antara pelayanan phlebotomy dengan kepuasan pasien di laboratorium klinik RS Pusat TNI Angkatan Udara Dr. Suhardi Hardjolukito Yogyakarta.

\section{METODE}

Jenis penelitian ini adalah penelitian observasional yang dianalisis secara kuantitatif dengan metode cross sectional study Populasi dalam penelitian ini adalah pasien yang melakukan pemeriksaan laboratorium di RS Pusat TNI AU Dr. Suhardi Hardjolukito Yogyakarta.

Sampel dalam penelitian ini adalah pasien rawat jalan yang melakukan pemeriksaan laboratorium di RSPAU Dr. Suhardi Hardjolukito Yogyakarta, dengan menggunakan teknik sampling : acak sederhana (simple random sampling).

Jumlah sampel pasien ditentukan dengan dasar perhitungan menggunakan rumus Slovin sebagai berikut:

$$
\text { Rumus : } \mathrm{n}=\frac{\mathrm{N}}{1+\mathrm{N}\left(\mathrm{d}^{2}\right)}
$$

Keterangan :

$\mathrm{n}$ : Besar sampel

$\mathrm{N}$ : Besarnya populasi. dihitung berdasarkan rata- rata kunjungan pasien rawat jalan selama 1 tahun yaitu sebanyak 1.534 pasien.

d2 : Tingkat kepercayaan $(0,01)$

Maka jumlah sampel dalam penelitian ini adalah :

$$
\begin{array}{ll}
n & : \frac{1534}{1+1534(0,01)} \\
n & : \frac{1534}{1+15,34} \\
n & : \frac{1534}{16,34} \\
n & : 93,880049 .
\end{array}
$$

Berdasarkan perhitungan tersebut dapat diketahui bahwa besar sampel adalah 93, 8800049 dibulatkan menjadi 94 responden.

a. Kriteria inklusi

Kriteria inklusi dalam penelitian ini adalah :

1) Laki- laki dan perempuan

Usia minimal 20 tahun.

2) Pernah menerima pelayanan pemeriksaan di Rumah Sakit Pusat TNI Angkatan Udara Dr. Suhardi Hardjolukito Yogyakarta lebih dari satu kali.

3) Bersedia menjadi responden penelitian, dengan kesediaan responden mengisi surat persetujuan menjadi responden.

b. Kriteria ekslusi

1) Balita dan anak-anak

2) Pasien dengan cacat psikis dan mengalami gangguan kesadaran

3) Pasien yang menerima pelayanan pemeriksaan di Rumah Sakit Pusat TNI Angkatan Udara Dr. Suhardi Hardjolukito Yogyakarta hanya satu kali.

Penelitian ini dilaksanakan pada tanggal 21 
Agustus sampai dengan 6 September 2016. Dilakukan di laboratorium klinik RS Pusat TNI Angkatan Udara Dr. Suhardi Hardjolukito Yogyakarta. Variabel bebas dalam penelitian ini adalah pelayanan phlebotomy, sedangkan variabel terikat adalah kepuasan pasien.

Teknik pengumpulan data dilakukan dengan menggunakan observasi, kuisioner (yang sudah diilakukan uji validitas dan uji reliabillitas) dan dokumentasi. Teknik pengukuran untuk menilai pelayanan phlebotomy menggunakan observasi partisipasif. Penentuan skor tiap item kegiatan dengan cara memberi skor 1 untuk kegiatan yang dilakukan secara benar sesuai dengan standar pelayanan phlebotomy dan skor 0 untuk kegiatan yang tidak dilakukan atau salah (tidak sesuai dengan standar phlebotomy), kemudian dilakukan penjumlahan skor masing- masing item kegiatan ${ }^{6}$

Persentase pencapaian pencapaian pada item pelayanan phlebotomy dilakukan dengan menggunakan rumus:

$$
P=\frac{F}{N} \quad X 100 \%
$$

\section{Keterangan:}

$P$ : Persentase

$\mathrm{F}$ : Jumlah skor tiap item kegiatan

$\mathrm{N}$ : Jumlah item yang diobservasi

Nilai yang diperoleh dari perhitungan, dapat dikonversikan ke dalam kategori sebagai berikut :

$$
\begin{array}{ll}
\text { Baik } & : 80 \% \text { sampai } 100 \% . \\
\text { Cukup } & : 60 \% \text { sampai } 79 \% . \\
\text { Kurang } & \text { : kurang dari } 59 \%
\end{array}
$$

Pengukuran tingkat kepuasan pasien diukur dengan menggunakan kuisioner. Penilaian kuisioner dilakukan dengan menggunakan skala likert.). Dalam penilaian ini menggunakan rentang penilaian 1 sampai 5. Untuk keperluan analisis kuantitatif, maka jawaban tersebut diberi skor:

a. Nilai 1 : tidak puas

b. Nilai 2 : kurang puas

c. Nilai 3 : cukup puas

d. Nilai 4 : puas

e. Nilai 5 : sangat puas.

Untuk mengetahui persentase tingkat kepuasan pelanggan terlebih dahulu dilakukan perhitungan dengan menggunakan rumus :

$$
P=\frac{A}{B} \times 100 \%
$$

Keterangan :
P : Persentase
A : Skor penilaian pasien
B : Jumlah skor kriterium (skor tertinggi)
Skor kategori skala likert ${ }^{6}$.

\section{$20-36 \%$ : Tidak puas \\ $37-53 \%$ : Kurang puas \\ $54-70 \%$ : Cukup puas \\ $71-87 \%$ : Puas \\ $88-100 \%$ : Puas}

Kemudian data yang diperoleh dianalisis dengan analisis statistik yang digunakan untuk mencari hubungan antara kepuasan pasien terhadap pelayanan pelayanan phlebotomy di laboratorium RS Pusat TNI Angkatan Udara Dr. Suhardi Hardjolukito Yogyakarta berdasarkan lima dimensi mutu pelayanan (kehandalan, responsivitas, jaminan, emphati dan bukti fisik). Analisis statistik menggunakan uji korelasi product moment ${ }^{8}$. Uji korelasi dengan product moment digunakan untuk mengukur hubungan dari dua variabel dengan skala data interval dengan bantuan program SPSS, pada taraf signifikansi $(\alpha) 0,1$. Jika $P$ hitung lebih kecil dari 0,1 , maka dapat diambil kesimpulan bahwa terdapat hubungan antara pelayanan pelayanan phlebotomy dengan kepuasan pasien di laboratorium RS Pusat TNI Angkatan Udara Dr. Suhardi Hardjolukito .

\section{HASIL}

Pengujian kuesioner dengan mengunakan uji validitas dan uji reliabilitas. Pengujian dilakukan dengan pengisian kuisioner pada tanggal 14 sampai dengan 16 Agustus 2016 terhadap 34 orang pasien rawat jalan di Rumah Sakit Dr. Soetarto Yogyakarta.

Uji validitas dilakukan dengan menghitung nilai korelasi antara skor masing-masing pernyataan dengan skor total dengan keseluruhan 30 butir pernyataan, memakai rumus teknik korelasi Product Moment Pearson yang diolah dengan software SPSS versi 19.00. Hasil pengujian validitas ditemukan empat pertanyaan yang dinyatakan tidak valid karena nilai signifikansi( p) kurang dari $10 \%$ atau kurang dari 0,1 , sehingga keempat pertanyaan pada kuisioner yang tidak valid direduksi atau dihilangkan. Setelah proses reduksi tersebut, maka tersisa 26 pertanyaan yang digunakan dalam penelitian.

Uji reliabilitas dilakukan dengan metode Alpha (Cronbach's) bantuan software SPSS versi 19.00, di peroleh hasil nilai cronbach's alpha sebesar 0,701 Oleh karena itu nilai cronbach's alpha lebih besar dari pada batas minimum reliabel 0,7 , maka dapat disimpulkan bahwa setiap item pertanyaan pada ke 26 kuisioner tersebut reliabel untuk penelitian.

\section{Karakteristik Responden}

Berdasarkan hasil kuisioner yang dilakukan terhadap 94 responden, diperoleh karakteristik responden sebagai berikut: 
Tabel 1. Karakteristik Responden

\begin{tabular}{lcc}
\hline $\begin{array}{c}\text { Karakteristik } \\
\text { Responden }\end{array}$ & $\begin{array}{c}\text { Jumlah } \\
\text { (Orang) }\end{array}$ & $\begin{array}{c}\text { Persentase } \\
(\%)\end{array}$ \\
\hline $\begin{array}{c}\text { Jenis Kelamin } \\
\text { Laki - laki }\end{array}$ & 43 & 45.8 \\
Perempuan & 51 & 54.2 \\
\hline Jumlah & 94 & 100 \\
\hline Usia (Tahun) & & \\
Usia 20 - 35 & 8 & 8.5 \\
Usia > 35 & 86 & 91.5 \\
\hline Jumlah & 94 & 100 \\
\hline Tingkat Pendidikan & & \\
SMP & 29 & 30.8 \\
SMA / Sederajat & 45 & 47.9 \\
Diploma & 13 & 13.8 \\
Sarjana & 7 & 7.5 \\
\hline Jumlah & 94 & 100 \\
\hline Pekerjaan & & \\
Pelajar/Mahasiswa & 2 & 2.1 \\
SWASTA & 42 & 44.7 \\
PNS & 47 & 50 \\
TNI & 3 & 3.2 \\
\hline Jumlah & 94 & 100 \\
\hline Jumlah Kunjungan & & \\
2- 3 Kali & 18 & 19.1 \\
4- 5 Kali & 33 & 35.1 \\
>5Kali & 43 & 45.8 \\
\hline Jumlah & 94 & 100 \\
\hline
\end{tabular}

Responden lanjut usia paling banyak melakukan pemeriksaan laboratorium yaitu sebanyak $38,3 \%$, Hal ini disebabkan karena pasien lanjut usia sudah mengalami kemunduran kondisi fisik dan psikologis yang berkaitan dengan proses penuaan sehingga lebih rentan terkena penyakit. Sehingga pasien usia lanjut lebih sering melakukan pemeriksaan kesehatan.

Berdasarkan jumlah kunjungan responden, pada penelitian ini paling banyak adalah responden yang telah melakukan pemeriksaan laboratorium lebih dari 5 kali sebesar $45,8 \%$. Kunjungan pasien rawat jalan di laboratorium klinik Rumah Sakit Pusat TNI AU Dr. Suhardi Hardjolukito Yogyakarta sebagian besar adalah pelanggan lama, yang secara rutin melakukan pemeriksaan laboratorium.

Sedangkan dari status responden dapat diketahui bahwa jumlah kunjungan responden pada penelitian ini paling banyak adalah responden yang menggunakan layanan Askes.. Askes atau asuransi kesehatan adalah salah satu asuransi yang paling diminati oleh masyarakat luas, baik PNS, militer maupun swasta. Jenis pekerjaan responden pada penelitian ini paling banyak adalah PNS sebanyak $50,0 \%$, TNI sebanyak $3 \%$ dan swasta sebesar $45 \%$. Sehingga dapat diambil kesimpulan bahwa pengguna layanan Askes wajib sebagian besar adalah PNS dan Militer, sedangkan yang lain adalah pengguna Askes swasta.

Observasi Pelayanan Phlebotomy
Berdasarkan hasil observasi yang dilakukan terhadap 94 responden untuk menilai pelayanan phlebotomy yang dilakukan oleh analis laboratorium, diperoleh hasil yaitu: dimensi kehandalan didapatkan persentase pelayanan phlebotomy sebesar $97,0 \%$, termasuk dalam kategori baik. Dimensi responsivitas sebesar 97,8\%, termasuk dalam kategori baik. Dimensi jaminan $73,6 \%$, termasuk dalam kategori cukup. Dimensi empati $98,4 \%$, termasuk dalam kategori baik, dan pada dimensi wujud diperoleh persentase pelayanan phlebotomy sebesar $74,2 \%$, termasuk dalam kategori cukup.

Kepuasan Pelanggan

Berdasarkan hasil pengisian kuisioner yang dilakukan terhadap 94 responden untuk menilai kepuasan pasien, masing- masing item kuisioner diberi kode K1 sampai K26. Diperoleh hasil sebagai berikut:

1. Dimensi Kehandalan

Tabel 2. Distribusi Frekuensi Dimensi

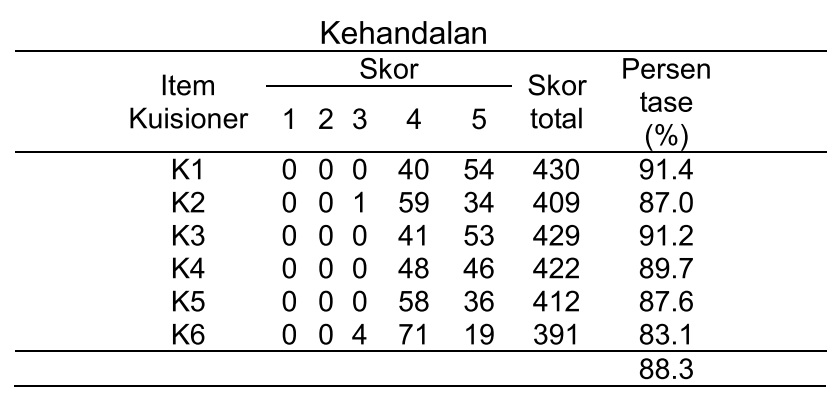

Pada dimensi kehandalan didapatkan persentase tingkat kepuasan pelanggan sebesar $88,3 \%$, termasuk dalam kategori sangat puas.

2. Dimensi Responsivitas

Tabel 3. Distribusi Frekuensi Dimensi Responsivitas

\begin{tabular}{|c|c|c|c|c|c|c|}
\hline \multicolumn{7}{|c|}{ Responsivitas } \\
\hline \multirow{2}{*}{$\begin{array}{c}\text { Item } \\
\text { Kuisioner }\end{array}$} & \multicolumn{4}{|c|}{ Skor } & \multirow{2}{*}{$\begin{array}{l}\text { Skor } \\
\text { total }\end{array}$} & \multirow{2}{*}{$\begin{array}{l}\text { Persen } \\
\text { tase(\%) }\end{array}$} \\
\hline & 12 & 3 & 4 & 5 & & \\
\hline K7 & 0 & 0 & 40 & 41 & 404 & 85.9 \\
\hline $\mathrm{K} 8$ & 0 & $0 \quad 20$ & 41 & 33 & 389 & 82.7 \\
\hline $\mathrm{K} 9$ & 0 & $0 \quad 21$ & 42 & 31 & 388 & 82.5 \\
\hline K10 & 0 & $0 \quad 15$ & 44 & 35 & 396 & 84.2 \\
\hline $\mathrm{K} 11$ & 0 & $0 \quad 13$ & 49 & 32 & 395 & 84.0 \\
\hline \multirow[t]{2}{*}{ K12 } & 0 & $0 \quad 13$ & 49 & 32 & 395 & 84.0 \\
\hline & & & & & & 83.8 \\
\hline
\end{tabular}

Pada dimensi responsivitas didapatkan persentase tingkat kepuasan pelanggan sebesar $83,8 \%$, termasuk dalam kategori puas.

3. Dimensi Jaminan

Tabel 4. Distribusi Frekuensi Dimensi Jaminan

\begin{tabular}{|c|c|c|c|c|c|c|}
\hline \multirow{2}{*}{$\begin{array}{c}\text { Item } \\
\text { Kuisioner }\end{array}$} & \multicolumn{4}{|c|}{ Skor } & \multirow{2}{*}{$\begin{array}{l}\text { Skor } \\
\text { total }\end{array}$} & \multirow{2}{*}{$\begin{array}{l}\text { Persen } \\
\text { tase }(\%)\end{array}$} \\
\hline & 12 & 3 & 4 & 5 & & \\
\hline K13 & 00 & 8 & 69 & 17 & 385 & 81.9 \\
\hline K14 & 00 & 0 & 61 & 33 & 409 & 87.0 \\
\hline K15 & 00 & 0 & 59 & 35 & 411 & 87.4 \\
\hline K16 & 00 & 1 & 52 & 41 & 416 & 88.5 \\
\hline K17 & 00 & 0 & 56 & 38 & 414 & 88.0 \\
\hline \multirow[t]{2}{*}{ K18 } & 00 & 0 & 49 & 45 & 419 & 89.1 \\
\hline & & & & & & 86.9 \\
\hline
\end{tabular}


Pada dimensi jaminan didapatkan persentase tingkat kepuasan pelanggan sebesar $86,9 \%$, termasuk dalam kategori puas.

4. Dimensi Empati

Tabel 5. Distribusi Frekuensi Dimensi Empati

\begin{tabular}{cccccccc}
\hline \multirow{2}{*}{$\begin{array}{c}\text { Item } \\
\text { Kuisioner }\end{array}$} & \multicolumn{4}{c}{ Skor } & $\begin{array}{c}\text { Skor } \\
\text { total }\end{array}$ & $\begin{array}{c}\text { Persen } \\
\text { tase }(\%)\end{array}$ \\
\cline { 2 - 6 } & 1 & 2 & 3 & 4 & 5 & & \\
\hline K19 & 0 & 0 & 0 & 46 & 48 & 424 & 90.2 \\
K20 & 0 & 0 & 2 & 56 & 36 & 410 & 87.2 \\
K21 & 0 & 0 & 0 & 54 & 40 & 416 & 88.5 \\
K22 & 0 & 0 & 13 & 59 & 22 & 385 & 81.9 \\
K23 & 0 & 2 & 11 & 52 & 29 & 390 & 82.9 \\
\hline
\end{tabular}

Pada dimensi empati didapatkan persentase tingkat kepuasan pelanggan sebesar $86,1 \%$, termasuk dalam kategori puas.

5. Dimensi Wujud

Tabel 6. Distribusi Frekuensi Dimensi Wujud

\begin{tabular}{cccccccc}
\hline Item & \multicolumn{4}{c}{ Skor } & Skor & Persen \\
\cline { 2 - 6 } Kuisioner & 1 & 2 & 3 & 4 & 5 & total & tase(\%) \\
\hline K24 & 0 & 0 & 1 & 64 & 29 & 404 & 85.9 \\
K25 & 0 & 0 & 19 & 66 & 9 & 366 & 77.8 \\
K26 & 0 & 0 & 40 & 51 & 3 & 339 & 72.1 \\
\hline
\end{tabular}

Pada dimensi empati didapatkan persentase tingkat kepuasan pelanggan sebesar 78,6\%, termasuk dalam kategori puas.

Hubungan Pelayanan Phlebotomy Dengan Kepuasan Pasien

Analisa data untuk mengetahui ada atau tidaknya hubungan antara pelayanan phlebotomy dengan kepuasan pasien dengan menggunakan uji statistik : korelasi product moment dengan bantuan program SPSS 19 for windows. Hasil Uji Statistik dikatakan valid atau terdapat hubungan antara pelayanan phlebotomy dengan kepuasan pelanggan apabila didapatkan nilai $P$ hitung kurang dari 0,1 dengan tingkat kepercayaan sebesar $10 \%$.

Berdasarkan hasil uji korelasi product moment dapat didapatkan hasil sebagai berikut:

Tabel 7. Hasil Uji Statistik

\begin{tabular}{ccl}
\hline Dimensi & $\mathbf{P}$ & Kesimpulan \\
\hline Kehandalan & 0.04 & Ada Hubungan \\
Responsivitas & 0.083 & Ada Hubungan \\
Jaminan & 0.064 & Ada Hubungan \\
Empati & 0.063 & Ada Hubungan \\
Wujud & 0.073 & Ada Hubungan \\
Total & 0.072 & Ada Hubungan \\
\hline
\end{tabular}

Hubungan Pelayanan Phlebotomy Dengan Kepuasan Pasien Berdasarkan Berdasarkan Semua Dimensi/ Total. Hasil uji statistik diketahui nilai $P$ sebesar 0,072, maka $P$ hitung kurang dari 0,1 . Sehingga dapat disimpulkan bahwa ada hubungan antara pelayanan phlebotomy dengan kepuasan pasien di laboratorium klinik Rumah Sakit Pusat TNI AU Dr. Suhardi Hardjolukito.

\section{PEMBAHASAN}

Salah satu unsur kepuasan pasien adalah terpenuhinya keinginan pasien yang datang ke Rumah Sakit untuk mendapatkan pelayanan.

Hasil observasi pelayanaan phlebotomy didapatkan persentase rata- rata sebesar 97,0\% dan termasuk dalam kategori baik. Hal ini menunjukan bahwa kesesuaian prosedur pelayanan phlebotomy atau pengambilan darah vena di laboratorium klinik Rumah Sakit Pusat TNI AU Dr. Suhardi Hardjolukito Yogyakarta sudah baik dan sesuai dengan standart mutu pelayanan phlebotomy di bidang kehandalan, yaitu dalam hal pelayanan tepat waktu bagi pasien, ketepatan dalam melakukan pengambilan darah vena atau phlebotomy sudah dilakukan dengan satu kali tusuk dan berhasil, serta terkait dengan kesesuaian identitas pasien yang diperiksa. Jika dilihat dari hasil kuisioner pada dimensi kehandalan diperoleh persentase kepuasan responden sebesar 88,3\%, termasuk dalam kategori sangat puas. Menunjukan bahwa responden merasa sangat puas terhadap pelayanan phlebotomy yang dilakukan oleh analis laboratorium dalam hal ketepatan waktu pemeriksaan serta kehandalan dan keterampilan analis laboratorium pada saat melakukan pengambilan darah vena.

Dimensi kehandalan merupakan dimensi yang paling penting dalam menilai kualitas pelayanan karena merupakan kemampuan untuk melaksanakan jasa yang dijanjikan dengan handal dan akurat, dalam hal ini jasa yang dijanjikan adalah pelayanan laboratorium ${ }^{3}$.

Untuk meningkatkan kehandalan dalam bidang pelayanan kesehatan maka perlu dilakukan penilaian secara berkala serta pelatihan untuk meningkatkan mutu pelayanan ${ }^{10}$. Dalam lingkup Rumah Sakit TNI Angkatan Udara Dr. Suhardi Hardjolukito Yogyakarta pelatihan dan pendidikan sangat penting, karena dengan adanya pendidikan dan pelatihan pengetahuan dan kualitas Sumber Daya Manusia menjadi semakin baik.

Hasil observasi pelayanaan phlebotomy pada dimensi responsivitas didapatkan persentase ratarata sebesar $97,8 \%$ dan termasuk dalam kategori baik, menunjukan bahwa kesediaan dan kesiapan analis laboratorium dalam melayani pasien di laboratorium klinik Rumah Sakit Pusat TNI AU Dr. Suhardi Hardjolukito Yogyakarta sudah baik dan sesuai dengan standart mutu pelayanan phlebotomy. Selain itu didukung dengan adanya kesigapan analis laboratorium ketika pasien membutuhkan bantuan terkait dengan penjelasan jenis pemeriksaan laboratorium yang akan dilakukan. 
Pada dimensi responsivitas didapatkan persentase tingkat kepuasan pelanggan sebesar $83,8 \%$, termasuk dalam kategori puas dan menunjukan bahwa responden merasa puas terhadap pelayanan yang dilakukan oleh analis laboratorium, karena perhatian, kepedulian analis laboratorium terhadap pasien sudah dilakukan dengan baik juga karena kesigapan analis laboratorium cepat tanggap pada saat melayani pasien di laboratorium, dan kesanggupan untuk menyelesaikan keluhan pasien.

Keinginan para karyawan untuk membantu pelanggan dan memberikan pelayanan dengan sigap merupakan salah satu aspek yang membuat seseorang merasa puas ${ }^{9}$.

Dimensi responsivitas atau daya tanggap merupakan kemampuan petugas dalam membantu pelanggan dan kesiapannya melayani semua prosedur dan bisa memenuhi harapan pelanggan ${ }^{10}$.

Pada dimensi jaminan, hasil observasi pelayanaan phlebotomy didapatkan persentase rata- rata sebesar $73,6 \%$, termasuk dalam kategori cukup dan menunjukan bahwa pengetahuan dan kesopanan analis laboratorium untuk menunjukan kepercayaan dan keyakinan dalam melayani pasien di laboratorium klinik Rumah Sakit Pusat TNI AU Dr. Suhardi Hardjolukito Yogyakarta harus ditingkatkan, karena pada saat observasi ditemukan bahwa semua analis laboratorium belum sepenuhnya menggunakan alat pelindung diri (APD) secara benar, terutama kesadaran analis laboratorium untuk menggunakan masker pada saat melakukan phlebotomy, karena analis laboratorium kurang peduli dan malas menggunakan alat pelindung diri (masker), padahal di laboratorium klinik sudah tersedia masker tersebut dan sesuai dengan Standart Operasional Prosedure (SOP) yang berlaku di laboratorium diwajibkan untuk memakai alat pelindung diri pada saat bekerja, seperti : jas laboratorium, sarung tangan dan masker.

Alat Pelindung Diri adalah seperangkat alat yang digunakan petugas untuk melindungi sebagian atau seluruh tubuhnya dari adanya potensi bahaya kecelakaan kerja dan kontaminasi ${ }^{11}$. Persentase tingkat kepuasan pelanggan pada dimensi jaminan didapatkan sebesar $86,9 \%$, termasuk dalam kategori puas. Responden merasa puas terhadap pelayanan yang dilakukan oleh analis laboratorium dalam hal pengetahuan dan kesopanan serta kemampuan analis laboratorium untuk menunjukan kepercayaan dan keyakinan.

Hasil skoring pada dimensi jaminan menunjukan bahwa analis laboratorium dinilai mampu untuk menjalankan tugas dan kewajiban profesi yang dimiliki, selain itu jaminan yang diberikan oleh Rumah Sakit terkait pelayanan laboratorium yang dilakukan bagi pelanggan misalnya jaminan memperoleh informasi tentang persiapan pasien sebelum melakukan pemeriksaan.

Dari dimensi empati, hasil observasi pelayanaan phlebotomy didapatkan persentase rata- rata sebesar $98,4 \%$, termasuk dalam kategori baik, yang menunjukan bahwa kepedulian dan perhatian analis laboratorium dalam melayani pasien di laboratorium klinik Rumah Sakit Pusat TNI AU Dr. Suhardi Hardjolukito Yogyakarta sudah baik dan sesuai dengan standart mutu pelayanan phlebotomy di bidang empati, karena analis laboratorium mampu memberikan perhatian khusus kepada pasien dan mampu memahami kebutuhan pasien. Didukung dengan adanya kemudahan analis laboratorium ketika dihubungi oleh pasien jika pasien membutuhkan informasi apabila ada konfirmasi hasil laboratorium yang belum selesai atau tertunda, sehingga pasien merasa puas.

Persentase tingkat kepuasan pelanggan pada dimensi empati sebesar $86,1 \%$, termasuk dalam kategori puas. Responden merasa puas terhadap perhatian pribadi atau perhatian khusus analis laboratorium pada saat responden membutuhkan bantuan.

Dimensi Empati terkait dengan kepedulian dan perhatian khusus kepada setiap pengguna jasa, memahami kebutuhan pelanggan dan memberikan kemudahan untuk dihubungi setiap saat. Peranan sumber daya manusia yang berkualitas sangat menentukan mutu pelayanan tersebut, apabila pelanggan merasa nyaman, maka dapat mempengaruhi tingkat kepuasan pelanggan dan akan mendorong pelanggan untuk datang kembali.

Jika dilihat dari dimensi wujud, hasil observasi pelayanaan phlebotomy diperoleh hasil $74,2 \%$, termasuk dalam kategori cukup. Dimensi bukti fisik di laboratorium klinik Rumah Sakit Pusat TNI AU Dr. Suhardi Hardjolukito Yogyakarta sudah cukup baik. Ruang lingkup dalam dimensi wujud ini meliputi : kerapian analis laboratorium sudah bagus (jas laboratorium yang dipakai bersih dan rapi), ruangan untuk pengambilan sampel darah sudah bagus karena terlihat bersih dan nyaman, namun kelayakan sarana penunjang (ruang tunggu) di laboratorium masih kurang, karena belum tersedia ruang tunggu khusus untuk pasien yang akan melakukan pemeriksaan laboratorium, melainkan ruang tunggu tersebut menjadi satu dengan ruang tunggu pasien poliklinik rawat jalan.

Dimensi bukti fisik khususnya dalam hal kenyamanan tidak berhubungan langsung dengan efektivitas layanan kesehatan, tetapi mempengaruhi kepuasan pelanggan, apabila pelanggan merasa nyaman, maka akan mendorong pasien untuk datang kembali ke tempat tersebut.

Persentase tingkat kepuasan pelanggan sebesar 
$78,6 \%$, termasuk dalam kategori puas karena responden merasa puas terhadap penampilan fasilitas fisik dan perlengkapan yang memadai. Terapi pada item kuisioner nomor 26 sebagian besar responden merasa cukup puas dengan ruang tunggu. $\mathrm{Hal}$ ini disebabkan karena ruang tunggu di laboratorium RSPAU Dr. Suhardi Hardjolukito Yogyakarta kurang nyaman, karena posisi ruang tunggu yang terletak jadi satu dengan semua poliklinik rawat jalan, sehingga pada saat pelayanan dibuka, khususnya pada saat pagi hari ruangan penuh, sesak dan bising.

Berdasarkan hasil uji statistik menggunakan korelasi product moment dengan bantuan program SPSS 19 for windows, diperoleh hasil $P$ hitung 0,072 dibandingkan dengan taraf signifikansi $(\alpha) 0,1$. Karena hasil $P$ hitung lebih kecil dari a maka $\mathrm{H}_{1}$ diterima, sehingga dapat diambil kesimpulan bahwa terdapat hubungan antara pelayanan phlebotomy dengan kepuasan pasien di laboratorium klinik Rumah Sakit Pusat TNI AU Dr. Suhardi Hardjolukito Yogyakarta. Berdasarkan hasil tersebut dapat diambil kesimpulan bahwa pasien rawat jalan yang melakukan pemeriksaan di laboratorium klinik Rumah Sakit Pusat TNI AU Dr. Suhardi Hardjolukito Yogyakarta sudah merasa puas terhadap pelayanan laboratorium yang diberikan khususnya dalam hal pelayanan phlebotomy.

Kepuasan pelanggan dapat menjadi tolok ukur sebuah perusahaan atau instansi dalam melakukan perbaikan mutu pelayanan, karena kepuasan pelanggan merupakan tanggapan pelanggan terhadap kesesuaian tingkat kepentingan atau harapan pelanggan sebelum mereka menerima jasa pelayanan dan sesudah pelayanan tersebut mereka terima. Hasil pengukuran kepuasan pasien terhadap kualitas pelayanan yang telah dilakukan dapat digunakan sebagai bukti dan bahan pertimbangan untuk evaluasi perbaikan kualitas pelayanan di waktu yang akan datang.

\section{KESIMPULAN}

Berdasarkan Hasil Penelitian, dapat diambil kesimpulan sebagai berikut:

1. Hasil penelitian dari 94 responden pasien rawat jalan, dapat diambil kesimpulan bahwa ada hubungan antara pelayanan phlebotomy dengan kepuasan pasien di laboratorium klinik Rumah Sakit TNI AU Dr. Suhardi Hardjolukito Yogyakarta dengan $P$ kurang dari 0,1 .

2. Dimensi kualitas pelayanan yang menentukan kepuasan pasien berdasarkan urutan skor tertinggi, yaitu :

a. Dimensi kehandalan dengan skor persentase kepuasan rata - rata $88,3 \%$, termasuk dalam kategori sangat puas. b. Dimensi jaminan dengan skor persentase kepuasan rata - rata $86,9 \%$, termasuk dalam kategori sangat puas.

c. Dimensi empati dengan skor persentase kepuasan rata - rata $86,1 \%$, termasuk dalam kategori sangat puas.

d. Dimensi reponsivitas dengan skor persentase kepuasan rata - rata $83,8 \%$, termasuk dalam kategori puas.

e. Dimensi wujud dengan skor persentase kepuasan rata - rata $78,6 \%$, termasuk dalam kategori puas.

\section{SARAN}

1. Bagi Rumah Sakit TNI AU Dr. Suhardi Hardjolukito Yogyakarta

a. Penataan ruang tunggu yang bercampur dengan poliklinik penyakit dalam dan poliklinik rawat jalan yang tata ruangannya sempit dan kurang cahaya.

b. Memberikan pelatihan bagi analis laboratorium.

c. Evaluasi penggunaan alat pelindung diri bagi petugas laboratorium secara rutin.

2. Bagi Analis Laboratorium Klinik

Pemakaian alat pelindung diri (APD) harus diperhatikan dan digunakan secara lengkap seperti : jas laboratorium, sarung tangan dan masker pada saat melakukan pengambilan darah vena atau phlebotomy.

\section{DAFTAR PUSTAKA}

1. Febrianti, I. (2010). Peningkatan Mutu Tenaga Kesehatan Melalui Pengaturan Sertifikasi Dan Registrasi. Jakarta: Depkes.

2. Keputusan Menteri Kesehatan Republik Indonesia Nomor: 370/MENKES/SK/III/2007 tentang Standar Profesi Ahli Teknologi Laboratorium Kesehatan.

3. Kotlerr, P. (2009). Manajemen Pemasaran Edisi 13 jilid 2. Jakarta: Erlangga.

4. Pohan , I. (2006). Jaminan Mutu Layanan Kesehatan: Dasar- Dasar Pengertian Dan Penerapan. Jakarta: EGC.

5. Djaelani, H.A. (2009). Dimensi Mutu Jasa Pelayanan Rumah Sakit Merupakan Kepuasan Pelanggan Dan Objek Hukum Kesehatan. Jakarta: Depkes.

6. Sugiyono. (2010). Metode Penelitian Bisnis. Bandung: Alfabeta.

7. Arikunto, S. (2010). Prosedur Penelitian Suatu Pendekatan Praktik Edisi Revisi. Jakarta: PT Rineka Cipta.

8. Riwidikdo, H. (2008). Statistika Kesehatan. 
64 Jurnal Teknologi Kesehatan, Volume 13, Nomor 2, September 2017, hlm. 58-64

Jogjakarta: Mitra Cendikia.

9. Tjiptono, F. (2005). Service, Quality and satisfaction. Yogyakarta: Andi Ofsett.

10.Muninjaya, G. (2011). Manajemen Mutu Pelayanan
Kesehatan. Jakarta: EGC.

11.Habsari, N.D. (2003). Penggunaan Alat Pelindung Diri Bagi Petugas. Bunga Rampai Hiperkes. Semarang: UNDIP. 